\title{
Hubungan Bobot Isi dan Kemantapan Agregat Tanah dengan Biomassa Tanaman Jagung Manis dan Cabai Merah setelah diberikan Kombinasi Terak Baja dan Bokashi Sekam Padi pada Andisol, Lembang
}

\author{
Henly Yulina ${ }^{*}$, Rina Devnita ${ }^{2}$ dan Rachmat Harryanto ${ }^{3}$ \\ ${ }^{1}$ Fakultas Pertanian, Universitas Wiralodra, Indramayu \\ Jl. Ir. H. Juanda KM 3 Indramayu \\ 2, 3Fakultas Pertanian, Universitas Padjadjaran \\ *Alamat korespondensi: henlyyulina2089@unwir.ac.id
}

\begin{abstract}
Relationship between bulk density and soil agaregate stability on biomass of sweet corn and red chili after given combination steel slag and bokashi of husk on Andisol Lembang
\end{abstract}

The objective of this research was to find out relationship between bulk density and soil agaregate stability on biomass of sweet corn and red chili after given combination steel slag and bokashi of husk on Andisol Lembang.This study used a Randomized Block Design Factorial with two factors. The first factor was steel slag and the second factor was bokashi of husk. Each of them consisted of 4 levels of $0 \%, 2.5 \%, 5.0 \%$ and $7.5 \%$ with two replications. The result of this research showed there was relationship between bulk density and soil agaregate stability on biomass of sweet corn and red chili, however only the biomass of red chili was influenced of bulk density and soil agaregate stability.

Keywords: Steel slag, Bokashi of husk, Bulk density, Soil agaregate stability, Plant biomass

\begin{abstract}
ABSTRAK
Penelitian ini bertujuan untuk mengetahui hubungan antara bobot isi dan kemantapan agregat tanah terhadap biomassa tanaman jagung manis dan cabai merah setelah diberikan kombinasi terak baja dengan bokashi sekam padi pada Andisol Lembang. Penelitian menggunakan Rancangan Acak Kelompok Pola Faktorial dengan dua faktor. Faktor pertama terak baja dan faktor kedua bokashi sekam padi masing-masing 4 taraf yaitu $0 \%, 2,5 \%, 5,0 \%$, dan 7,5\%, diulang dua kali. Hasil penelitian menunjukkan bahwa terdapat hubungan antara bobot isi dan kemantapan agreagat tanah dengan biomassa tanaman jagung manis dan cabai merah, namun hanya biomassa tanaman cabai merah yang dipengaruhi oleh bobot isi dan kemantapan agregat tanah.
\end{abstract}

Kata Kunci: Terak baja, Bokashi sekam padi, Bobot isi, Kemantapan agregat, Biomassa tanaman

\section{PENDAHULUAN}

Andisol adalah tanah yang berkembang dari bahan induk abu gunungapi (Devnita, 2010) dengan sifat tanah andik yang dicirikan dengan kandungan C-organik yang kurang dari 25\%, bobot isi kurang dari $0,9 \mathrm{~g} / \mathrm{cm}^{3}$, retensi $\mathrm{P}$ lebih dari $85 \%$ dan jumlah persentase $\mathrm{Al}+1 / 2 \mathrm{Fe}$ lebih dari 2,0\% di ekstrak dengan ammonium oksalat (Soil Survey Staff, 2010). Andisol mempunyai potensi tinggi untuk pertanian karena memiliki beberapa sifat fisika dan kimia tanah yang baik, seperti bobot isi tanah rendah, permeabilitas tanah tinggi, kandungan bahan organik tinggi dan kandungan unsur hara yang tinggi, meskipun demikian Andisol memiliki beberapa kendala diantaranya ketersediaan unsur $P$ yang rendah.

Rendahnya ketersediaan $\mathrm{P}$ pada Andisol disebabkan oleh fraksi koloidnya yang didominasi oleh mineral ordo kisaran pendek, seperti alofan, imogolit, ferihidrit dan kompleks Al-humus (Hardjowigeno, 2003; Tan, 1998). Alofan adalah mineral liat tanah yang sangat reaktif (Sukmawati, 2011) karena mempunyai permukaan spesifik yang luas (Uehara \& Gillman, 1981) dan mempunyai banyak gugus fungsional aktif, seperti $\mathrm{Fe}$ dan $\mathrm{Al}$ 
(Bohn et al., 1979) yang bermuatan positif, sehingga dapat mengikat fosfat yang bermuatan negatif. Hal ini yang menyebabkan retensi $P$ pada Andisol sangat tinggi lebih dari $85 \%$.

Silikat dan bahan organik merupakan anion yang memiliki muatan negatif yang tinggi, sehingga dapat melepaskan anion-anion seperti fosfat dari kompleks jerapan (Tan, 1998). Pada penelitian ini silikat terdapat dalam terak baja dan bahan organik dalam bentuk bokashi sekam padi. Pemberian silikat dapat melepaskan ion fosfat dari tapak jerapan dan dapat menurunkan retensi fosfat. Di sisi lain bokashi adalah bahan organik yang difermentasikan dengan EM4 atau Effective Microorganism 4 yang dapat memperbaiki sifat fisika tanah dengan membentuk dan memantapkan agregat tanah. Tanah dengan agregat yang mantap akan mampu mempertahankan kondisi tanah dari serangan energi luar, seperti energi kinetik curah hujan dan pengolahan tanah (Yulnafatmawita dkk., 2012). Selain itu bahan organik mampu mengikat butir tunggal menjadi agregat dari agregat mikro menjadi agregat meso dan makro yang mempunyai ruang pori antara agregat tersebut. Semakin besar agregat yang terbentuk, ruang pori yang bersebelahan dengan agregat juga semakin besar (Yulnafatmawita dkk., 2010) dan bobot isi tanah semakin rendah. Penambahan bahan organik juga dapat meningkatkan biomassa tanaman (Yulnafatmawita, 2006).

Tanaman yang digunakan pada penelitian ini adalah jagung manis dan cabai merah. Jagung manis dan cabai merah merupakan tanaman hortikultura yang bernilai tinggi bagi produsen dan konsumennya. Produsen memiliki potensi untuk mendapatkan pendapatan yang lebih tinggi dari usaha yang dilakukannya karena pada umumnya komoditas sayuran memiliki harga jual dan skala komersialisasi yang lebih tinggi dibandingkan komoditas pangan, sedangkan bagi konsumen, memberikan manfaat yang baik untuk kesehatan karena memiliki kandungan gizi yang cukup tinggi (Perdana dkk., 2013). Di Jawa Barat, luas area panen jagung manis adalah 138,957 ha dengan produksi 412,020 ton dan hasil rata-rata 29,65 kuintal per ha (Nurawan dkk., 2010) dan luas area panen cabai merah sebesar 171,895 ha dengan produksi 484,36 ton dan hasil rata-rata 48,93 kuintal per ha (Nurlenawati dkk., 2010). Jagung manis dan cabai merah menghasilkan buah dan biji sebagai produk pertaniannya.

Unsur hara P merupakan unsur hara makro yang sangat dibutuhkan tanaman untuk pertumbuhan dan produksi tanaman (Rasyid, 2012) salah satunya untuk merangsang pertumbuhan akar, mempercepat kematangan buah dan biji (Suyono dkk., 2008). Pemberian terak baja dan bokashi sekam padi diharapkan dapat mengurangi retensi $\mathrm{P}$, menurunkan bobot isi tanah dan meningkatkan kemantapan agregat tanah pada tanaman jagung manis dan cabai merah.

\section{BAHAN DAN METODE}

Penelitian ini dilakukan di Kebun Percobaan Balai Penelitian Tanaman Sayuran (Balitsa) Lembang, dari September sampai February 2014. Penelitian ini mengguakan Rancangan Acak Kelompok (RAK) pola faktorial dengan dua faktor. Faktor pertama adalah terak baja dan faktor kedua adalah bokashi sekam padi, masing-masing terdiri dari empat taraf, yaitu $0 \%, 2,5 \%, 5,0 \%$ dan $7,5 \%$ yang diulang sebanyak dua kali. Total kombinasi perlakuan adalah $4 \times 4 \times 2=32$ pot percobaan $\times 2$ tanaman $=64$ pot percobaan. Terak baja diperoleh dari PT. Krakatau Steel dan Bokashi sekam padi telah dibuat di Pedca Unpad. Kombinasi perlakuan dapat dilihat pada Tabel 1.

Tabel 1. Kombinasi perlakuan terak baja dan bokashi sekam padi

\begin{tabular}{ccccc}
\hline Terak Baja & \multicolumn{4}{c}{ Bokashi Sekam Padi (B) } \\
\cline { 2 - 5 }$(\mathrm{T})$ & $\mathrm{b}_{0}$ & $\mathrm{~b}_{1}$ & $\mathrm{~b}_{2}$ & $\mathrm{~b}_{3}$ \\
\hline $\mathrm{t}_{0}$ & $\mathrm{t}_{0} \mathrm{~b}_{0}$ & $\mathrm{t}_{\mathrm{b}} \mathrm{b}_{1}$ & $\mathrm{t}_{0} \mathrm{~b}_{2}$ & $\mathrm{t}_{\mathrm{b}} \mathrm{b}_{3}$ \\
$\mathrm{t}_{1}$ & $\mathrm{t}_{1} \mathrm{~b}_{0}$ & $\mathrm{t}_{1} \mathrm{~b}_{1}$ & $\mathrm{t}_{1} \mathrm{~b}_{2}$ & $\mathrm{t}_{1} \mathrm{~b}_{3}$ \\
$\mathrm{t}_{2}$ & $\mathrm{t}_{2} \mathrm{~b}_{0}$ & $\mathrm{t}_{2} \mathrm{~b}_{1}$ & $\mathrm{t}_{2} \mathrm{~b}_{2}$ & $\mathrm{t}_{2} \mathrm{~b}_{3}$ \\
$\mathrm{t}_{3}$ & $\mathrm{t}_{3} \mathrm{~b}_{0}$ & $\mathrm{t}_{3} \mathrm{~b}_{1}$ & $\mathrm{t}_{3} \mathrm{~b}_{2}$ & $\mathrm{t}_{3} \mathrm{~b}_{3}$ \\
\hline
\end{tabular}

Hubungan antara masing-masing perlakuan selanjutnya di analisis menggunakan model regresi linier sederhana menurut Gasperz (1991) seperti diuraikan di bawah. Kemudian berdasarkan model linier tersebut, maka disusun analisis regresi linier sederhana.

$Y=\beta_{0}+\beta_{1} X+\varepsilon$

$\hat{Y}=a+b X$

Keterangan:

$\hat{Y}=$ peubah tak bebas (biomassa tanaman)

$\mathrm{X}=$ peubah bebas (bobot isi, kemantapan agregat,

total porositas dan air tersedia)

a = koefisien intercept

$\mathrm{b}=$ koefisien regresi

Tanah yang digunakan dalam penelitian ini diambil dari beberapa titik di Balitsa dengan kedalaman 0-20 cm. Tanah kemudian dicampurkan 
dengan perlakuan dan dimasukkan kedalam 64 polybag (dengan ukuran 60 x $60 \mathrm{~cm}$ ). Inkubasi dilakukan selama 4 minggu. Selama inkubasi berlangsung, secara berkala (1 minggu 2 kali) akan dilakukan penimbangan berat tanah untuk mengetahui apakah terjadi penurunan berat tanah. Jika terjadi penurunan berat tanah selama inkubasi maka dilakukan pemberian air hingga mencapai berat tanah awal (kapasitas lapang).

Penanaman benih jagung manis dengan cara ditugal atau digarit. Jagung manis mencapai fase generatif akhir sekitar 80-100 hst (Zuraida, 2010) dengan jarak tanam $75 \mathrm{~cm}$ x $25 \mathrm{~cm}$. Pupuk yang digunakan adalah $300 \mathrm{~kg} / \mathrm{ha}$ Urea, $150 \mathrm{~kg} / \mathrm{ha}$ SP-36 dan $50 \mathrm{~kg} / \mathrm{ha} \mathrm{KCl}$ (Zuraida, 2010). Fase pertumbuhan vegetatif akhir berkisar antara 45-52 hari (Subekti dkk., 2007), ditandai oleh adanya cabang terakhir dari bunga jantan sebelum kemunculan bunga betina (silk/ rambut tongkol).

Cabai merah mencapai fase vegetatif akhir sekitar 45-60 hst (BPPP, 2011) dan dapat di panen setelah berumur 75-85 hst. Pupuk yang digunakan adalah $200 \mathrm{~kg}$ ha-1 Urea, $200 \mathrm{~kg}$ ha-1 SP-36 dan 200 $\mathrm{kg}$ ha-1 KCl dengan jarak tanam $60 \mathrm{~cm} \times 75 \mathrm{~cm}$
(Piay dkk., 2010). Panen dapat dilakukan beberapa kali (Piay dkk., 2010).

Sampel tanah di ambil pada setiap perlakuan dengan menggunakan ring sampel untuk analisis bobot isi tanah dan pengambilan bongkahan untuk analisis kemantapan agregat tanah. Penentuan bobot isi tanah dengan metode Bongkahan dan kemantapan agregat tanah dengan metode Loveday. Kegiatan analisis tanah dilakukan di Laboratorium Konservasi dan Fisika Tanah, Departemen Ilmu Tanah dan Sumberdaya Lahan, Fakultas Pertanian, Universitas Padjadjaran.

\section{HASIL DAN PEMBAHASAN}

\section{Hubungan Bobot Isi Tanah dengan Biomassa Tanaman Jagung Manis Setelah Panen dan Cabai Merah Setelah Vegetatif Akhir}

Salah satu faktor yang memengaruhi pertumbuhan tanaman adalah tinggi rendahnya bobot isi tanah. Pada penelitian ini terdapat hubungan antara bobot isi tanah dengan biomassa tanaman jagung manis dan cabai merah yang dapat dilihat pada Gambar 1 dan 2.

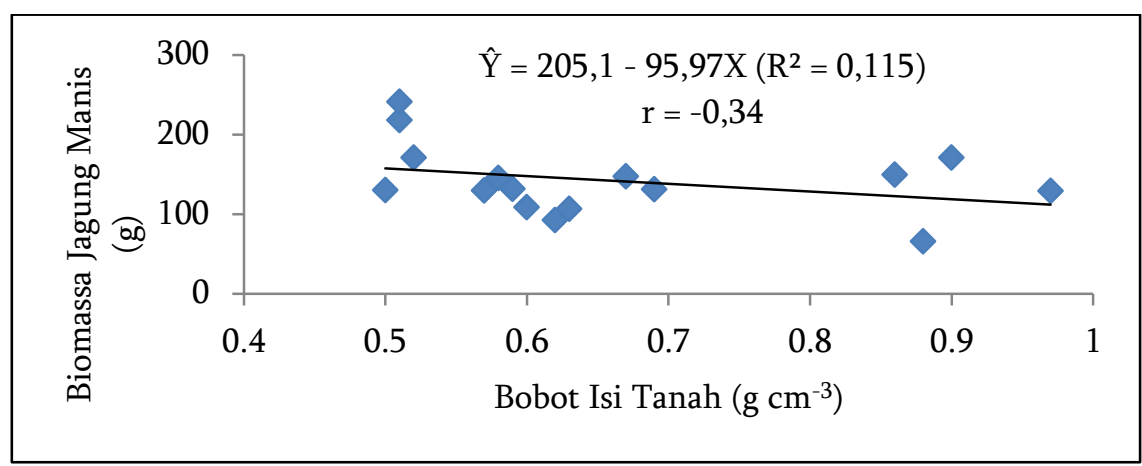

Gambar 1. Hubungan bobot isi tanah dengan biomassa tanaman jagung manis setelah panen

Data pada Gambar 1 menunjukkan bahwa bobot isi tanah $(\mathrm{X})$ mempunyai hubungan dengan biomassa tanaman jagung manis $(\mathrm{Y})$, semakin tinggi nilai bobot isi tanah maka biomassa tanaman jagung manis semakin kecil $(\mathrm{r}=-0,34)$. Berdasarkan persamaan regresi linier $\hat{Y}=205,1-95,97 X\left(R^{2}=\right.$ $0,115)$, biomassa tanaman jagung manis dipengaruhi oleh bobot isi tanah sebesar 34\%. Faktor-faktor lain memberikan pengaruh sebesar $66 \%$ terhadap biomassa tanaman jagung manis.

Data pada Gambar 2 menunjukkan bahwa bahwa bobot isi tanah (X) mempunyai hubungan dengan biomassa tanaman cabai merah (Y), semakin tinggi nilai bobot isi tanah maka biomassa tanaman cabai merah semakin kecil $(r=-0,55)$. Berdasarkan persamaan regresi linier $\hat{Y}=5,452-6,390 X\left(R^{2}=\right.$ $0,303)$, biomassa tanaman cabai merah dipengaruhi oleh bobot isi tanah sebesar 55\%. Faktor-faktor lain memberikan pengaruh sebesar $45 \%$ terhadap biomassa tanaman cabai merah. Berdasarkan data pada gambar hubungan bobot isi tanah dengan biomassa kedua tanaman di atas, maka disusun persamaan regresi ketiga tanaman yang dapat dilihat pada Tabel 3. 


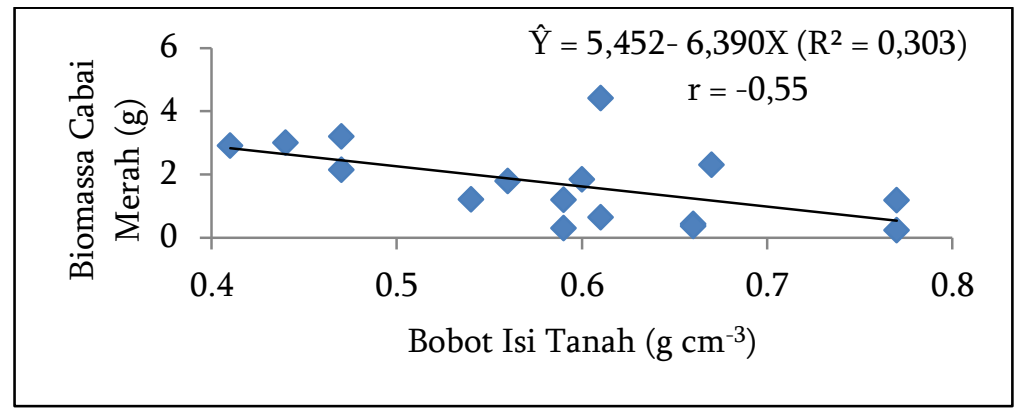

Gambar 2. Hubungan bobot isi tanah dengan biomassa tanaman cabai merah setelah vegetatif akhir

Tabel 3. Daftar persamaan regresi hubungan biomassa tanaman jagung manis dan cabai merah dengan bobot isi tanah

\begin{tabular}{lccc}
\hline \multicolumn{1}{c}{ Tanaman } & $\begin{array}{c}\text { Persamaan } \\
\text { regresi }\end{array}$ & $\mathrm{R}^{2}$ & $\mathrm{r}$ \\
\hline Jagung manis & $\hat{\mathrm{Y}}=205,1-95,97 \mathrm{X}$ & 0,115 & $-0,34$ \\
Cabai merah & $\hat{\mathrm{Y}}=5,452-6,390 \mathrm{X}$ & 0,303 & $-0,55^{*}$ \\
\hline Keterangan: 'berbeda nyata & &
\end{tabular}

Data pada Tabel 3 menunjukkan bahwa hanya biomassa tanaman cabai merah yang dipengaruhi oleh bobot isi tanah. Bobot isi tanah merupakan salah satu sifat fisika tanah yang digunakan untuk menilai kegemburan tanah. Pertumbuhan tanaman sangat dipengaruhi oleh bobot isi tanah. Hasil penelitian Hasanah (2009) menunjukkan bahwa semua parameter pertumbuhan yang diamati seperti tinggi tanaman, panjang akar, berat segar, kering akar dan kering pupus tanaman semuanya secara konsisten meningkat dengan semakin menurunnya bobot isi tanah.

Akar tanaman tumbuh dan berkembang cepat pada tanah yang sangat gembur, tetapi absorpsi air dan hara bisa terbatas karena kurangnya kontak antara akar dan partikel tanah atau larutan tanah. Pada penelitian ini hanya biomassa tanaman cabai merah yang sebagian besar dipengaruhi oleh bobot isi tanah. Hal ini disebabkan oleh sistem perakaran cabai merah yang agak menyebar dan lebih pendek dibandingkan jagung manis. Semakin panjang akar, maka diperlukan kekuatan penetrasi yang lebih besar untuk melewati atau menembus agregat tanah. Perkembangan akar sangat dipengaruhi oleh cara pengolahan tanah (Simanjuntak, 2005). Penanaman yang dilakukan dalam polibag menyebabkan tanah di bagian lebih dalam mengalami pemadatan, sehingga akar jagung manis yang tumbuh lebih panjang memerlukan kekuatan penetrasi akar yang lebih besar dibandingkan cabai merah. Hal ini menyebabkan pertumbuhan tanaman berkurang.

Menurut Hardjowigeno (1995), makin padat tanah maka makin tinggi bobot isinya yang berarti makin sulit tanah meneruskan air atau ditembus akar tanaman. Sejalan dengan hasil penelitian Matangaran dkk. (2010), kedalaman penetrasi akar dan pertumbuhan tinggi tanaman berkurang dengan meningkatknya kepadatan tanah, dengan terganggunya sistem perakaran maka akan terganggu pula proses-proses di dalam jaringan tanaman terutama penyerapan unsur hara melalui akar menuju bagian tanaman.

\section{Hubungan Kemantapan Agregat Tanah dengan Biomassa Tanaman Jagung Manis Setelah Panen dan Cabai Merah Setelah Vegetatif Akhir}

Susunan agregat tanah atau fragmen tanah memiliki pengaruh terhadap produksi tanaman. Hal ini dapat dilihat pada Gambar 3 dan 4 dimana terdapat hubungan antara kemantapan agregat tanah dengan biomassa tanaman jagung manis dan cabai merah.

Data pada Gambar 3 menunjukkan bahwa kemantapan agregat tanah (X) mempunyai hubungan dengan biomassa tanaman jagung manis $(\mathrm{Y})$, semakin stabil atau kecil nilai kemantapan agregat tanah maka biomassa tanaman jagung manis semakin besar $(r=-0,16)$. Berdasarkan persamaam regresi linier $\hat{Y}=165,0-8,846 X \quad\left(R^{2}=0,024\right)$, biomassa tanaman jagung manis dipengaruhi oleh kemantapan agregat tanah sebesar 16\%. Faktorfaktor lain memberikan pengaruh sebesar $84 \%$ terhadap biomassa tanaman jagung manis. 


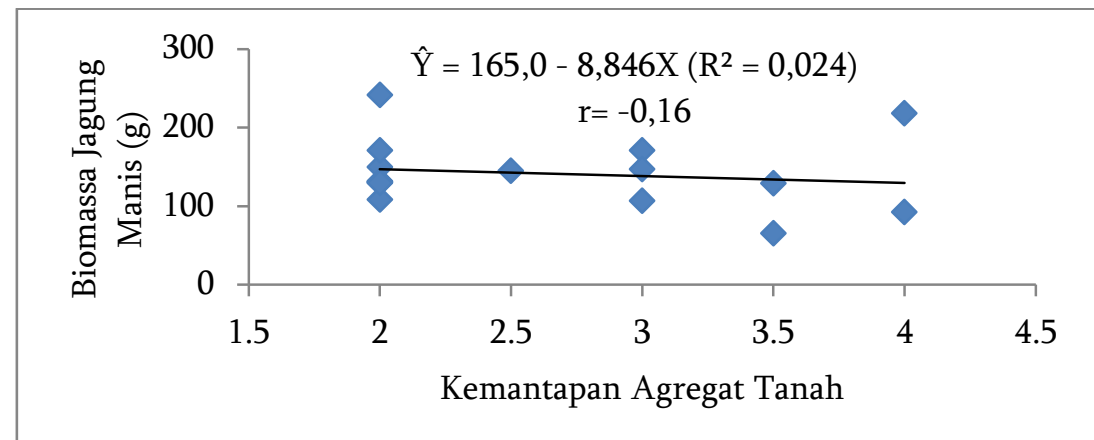

Gambar 3. Hubungan kemantapan agregat tanah dengan biomassa tanaman jagung manis setelah panen

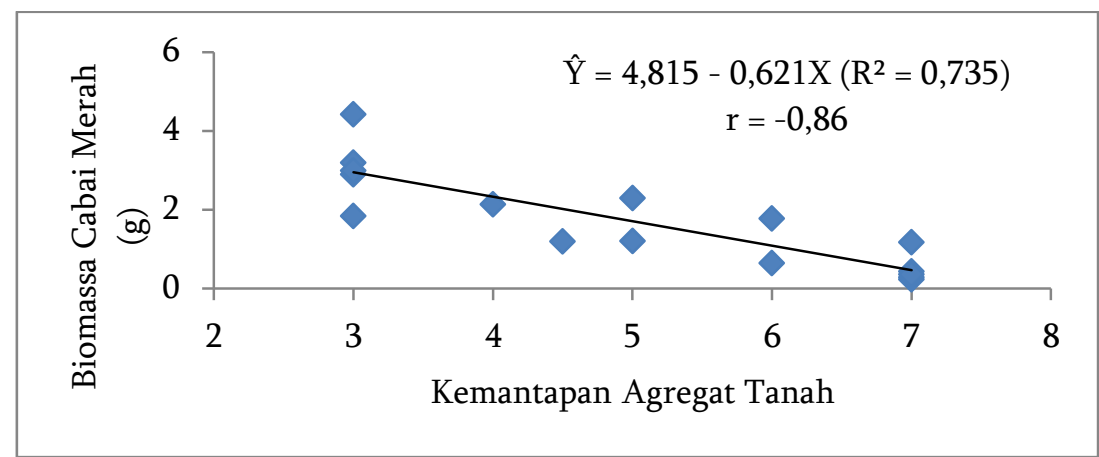

Gambar 4. Hubungan kemantapan agregat tanah dengan biomassa tanaman cabai merah setelah vegetatif akhir

Data pada Gambar 4 menunjukkan bahwa kemantapan agregat tanah (X) mempunyai hubungan dengan biomassa tanaman cabai merah $(\mathrm{Y})$, semakin stabil atau kecil nilai kemantapan agregat tanah maka biomassa tanaman cabai merah semakin besar $(r=-0,86)$. Berdasarkan persamaan regresi linier $\hat{Y}=-0,621 X+4,815\left(R^{2}=0,735\right)$, biomassa tanaman cabai merah dipengaruhi oleh kemantapan agregat tanah sebesar 86\%. Faktorfaktor lain memberikan pengaruh sebesar $14 \%$ terhadap biomassa tanaman cabai merah. Berdasarkan data pada gambar hubungan kemantapan agregat tanah dengan biomassa kedua tanaman di atas, maka disusun persamaan regresi ketiga tanaman yang dapat dilihat pada Tabel 4 .

Tabel 4. Daftar persamaan regresi hubungan biomassa tanaman jagung manis dan cabai merah dengan kemantapan agregat tanah

\begin{tabular}{llcc}
\hline \multicolumn{1}{c}{ Tanaman } & Persamaan Regresi & $\mathrm{R}^{2}$ & $\mathrm{r}$ \\
\hline Jagung manis & $\hat{\mathrm{Y}}=165,0-8,846 \mathrm{X}$ & 0,024 & $-0,16$ \\
Cabai merah & $\hat{\mathrm{Y}}=4,815-0,621 \mathrm{X}$ & 0,735 & $\left.-0,86^{*}\right)$ \\
\hline \multicolumn{4}{l}{ Keterangan: *berbeda nyata }
\end{tabular}

Data pada Tabel 4 menunjukkan bahwa hanya biomassa tanaman cabai merah yang dipengaruhi oleh kemantapan agregat tanah.
Kemantapan agregat hanya berpengaruh nyata terhadap biomassa tanaman cabai merah. Hal ini disebabkan oleh akar cabai merah yang lebih pendek dibandingkan jagung manis. Jagung manis yang memiliki akar lebih panjang, sebenarnya dapat mengambil unsur-unsur hara dan air yang lebih banyak untuk pertumbuhan tanaman, namun penanaman yang dilakukan di dalam polibag menyebabkan adanya keterbatasan ruang, sehingga semakin dalam tanah maka tanah tersebut akan semakin padat. Kedalaman penetrasi akar dan pertumbuhan tinggi tanaman akan berkurang dengan meningkatknya kepadatan tanah (Matangaran dkk., 2010).

Penetrasi akar sangat berperan dalam pembentukan agregat tanah, karena akar-akar tanaman akan mengeluarkan eksudat-eksudat akar yang akan mengikat partikel-partikel tanah membentuk agregat-agregat mikro menjadi agregat meso yang mempunyai ruang pori antara agregat tersebut. Susunan agregat tanah atau fragmen tanah memiliki pengaruh utama terhadap aerasi, ketersediaan air dan kekuatan tanah, sehingga berpengaruh terhadap pertumbuhan akar dan tajuk yang pada akhirnya berpengaruh terhadap produksi tanaman (Zorita et al., 2005). 
Kemantapan agregat tidak dapat dilepaskan dari sifat fisika lainnya. Biomassa tanaman cabai merah bukan hanya dipengaruhi oleh kemantapan agregat tanah, tetapi oleh bobot isi tanah. Perbedaan ukuran diameter agregat tanah memberikan hasil yang berbeda terhadap bobot isi tanah. Semakin kecil agregat tanah maka bobot isi tanah yang dihasilkan semakin besar, sehingga porositas berkurang. Pada ukuran diameter agregat yang halus $(<0,5 \mathrm{~mm})$ pori tanah yang terbentuk akan didominasi oleh pori mikro yang diameternya lebih kecil dibanding diameter akar, sehingga dibutuhkan kemampuan penetrasi akar yang lebih besar (Hasanah dkk., 2010) yang dapat menghambat pertumbuhan tanaman. Menurut Whiteley dan Dexter (1984) ketika akar tanaman yang berkembang dalam tanah bertemu dengan agregat tanah maka tiga kemungkinan bisa terjadi: (i) akar menembus agregat, (ii) akar mendorong agregat ke samping atau memindahkan partikel atau agregat tanah untuk menciptakan ruang yang dapat dimasuki akar dan (iii) akar membengkok untuk menghindari halangan.

Penggunaan polibag pada penelitian ini menyebabkan keterbatasan ruang dalam polibag, akar tanaman jagung manis yang terus tumbuh lebih panjang dibandingkan cabai merah akan mengikat partikel-partikel tanah dan membentuk agregat yang lebih halus sehingga bobot isi semakin besar dan pori mikro yang terbentuk lebih banyak dibandingkan pori meso dan makro (Hasanah dkk., 2010). Penetrasi akar jagung manis akan lebih besar daripada kondisi ketika ruang pori yang ada relatif sama atau lebih besar dari pada diameter akar. Hal ini menyebabkan pertumbuhan tanaman jagung manis lebih terhambat, sehingga hanya biomassa tanaman cabai merah yang sebagian besar dipengaruhi oleh kemantapan agregat tanah.

\section{SIMPULAN}

Terdapat hubungan antara bobot isi dan kemantapan agreagat tanah dengan biomassa tanaman jagung manis dan cabai merah, namun hanya biomassa tanaman cabai merah yang dipengaruhi oleh bobot isi dan kemantapan agregat tanah. Hal ini dapat disebabkan oleh sistem perakaran cabai merah yang agak menyebar dan lebih pendek dibandingkan jagung manis. Jagung manis yang memiliki akar lebih panjang dan penanaman yang dilakukan di dalam polibag menyebabkan adanya keterbatasan ruang, sehingga semakin dalam tanah maka tanah tersebut akan semakin padat dan kemantapan agregat yang terbentuk semakin stabil. Dengan demikian, akar tanaman sulit berkembang dan tidak dapat mensuplai air serta makanan untuk pertumbuhan dan perkembangan tanaman jagung manis tersebut.

\section{UCAPAN TERIMA KASIH}

Penulis mengucapkan terima kasih kepada Kepala Balai Penelitian Tanaman Sayuran (Balitsa), Lembang karena telah mengizinkan penggunaan lahan untuk penelitian Penulis.

\section{DAFTAR PUSTAKA}

Badan Penelitian dan Pengembangan Pertanian (BPPP). 2011. Kiat Sukses Berinovasi Cabai. Agroinovasi. Sinar Tani. Badan Penelitian dan Pengembangan Pertanian, Kementrian Pertanian. Edisi 2-8 Februari 2011 No. 3391.

Bohn, HL, BLMc Neal, and GA O'Connor. 1979. Soil Chemistry. John Willey and Sons, New York.

Devnita, R. 2010. Genesis dan Karakteristik Tanah Abu Gunungapi. Unpad Press, Bandung.

Harjdowigeno, S. 1995. Ilmu Tanah. Akademika Presindo, Jakarta.

Hardjowigeno, S. 2003. Klasifikasi Tanah dan Pedogenesis. Akademika Pressindo, Jakarta.

Hasanah, U. 2009. Respon tanaman tomat (Lycopersicum esculentum Mill) pada awal pertumbuhan terhadap keragaman ukuran agregat Entisol. J. Agroland. 16(2): 103-109.

Hasanah, U, Ardiyansyah, dan A Rosidi. 2010. Pertumbuhan awal dan evapotranspirasi aktual tanaman tomat (Lycopersicum esculentum Mill) pada berbagai ukuran agregat Inceptisols. J. Agroland. 17(1): 1117.

Matangaran, J, RC Wibowo, dan U Suwarna. 2010. Pertumbuhan semai sengon dan mangium pada tanah padat. Jurnal Ilmu Pertanian Indonesia. 15(3): 153-157.

Nurawan, A, M Djaeni, I Nurhati, dan Y Surdjanto. 2010. Keragaan Teknologi Budidaya Jagung Manis dalam Mendukung Sisitem Usahatani Terpadu di Kabupaten Majalengka dan Sukabumi. Balai Pengkajian Teknologi Pertanian Jawa Barat, Bogor.

Nurlenawati, N, A Jannah, dan Nimih. 2010. Respon pertumbuhan dan hasil tanaman cabai merah (Capsicum annum L.) varietas Prabu terhadap berbagai dosis pupuk fosfat dan 
bokashi jerami limbah jamur merang. Agrika. 4(1): 9-20.

Perdana, T, J Sauman, dan E Wulandari. 2013. Penerapan IPTEK untuk Meningkatkan Daya Saing Petani Sayuran dalam Memenuhi Permintaan Pasar Ekspor. Artikel Forum Tahunan LIPI 2013.

Piay, SS, A Tyasdjaja, Y Ermawati, dan FRP Hantoro. 2010. Budidaya dan Pascapanen Cabai Merah (Capsicum annuum L.). Balai Pengkajian Teknologi Pertanian Jawa Tengah. ISBN: 978-979-9007-54-4.

Rasyid, B. 2012. Aplikasi kompos kombinasi zeolit dan fosfat alam untuk peningkatan kualitas tanah Ultisol dan produktivitas tanaman jagung. Jurnal Agrisistem. 8(1): 13-22.

Simanjuntak, D. 2005. Peranan Trichoderma, micoriza dan fosfat terhadap tanaman kedelai pada tanah sangat masam (humitropets). Jurnal Penelitian Bidang Ilmu Pertanian. 3(1): 36-42.

Soil Survey Staff. 2010. Keys to Soil Taxonomy. United States Departement of Agriculture Natural Resources Conservation Service. Eleventh Edition.

Subekti, NA, Syafruddin, R Efendi, dan S Sunarti. 2007. Morfologi Tanaman dan Fase Pertumbuhan Jagung. Balai Penelitian Tanaman Serealia, Sulawesi.

Sukmawati. 2011. Jerapan P pada Andisol yang berkembang dari tuff vulkan beberapa gunung api di Jawa Tengah dengan pemberian asam humat dan asam silikat. Media Litbang Sulteng. 4(1): 30-36.

Suyono, AD, T Kurniatin, S Mariam, M Damayanti, T Syammusa, A Yuniarti, E Trinurani, dan Y Machfud. 2008. Pupuk dan Pemupukan. Unpad Press, Bandung.
Tan, KH. 1998. Principles of Soil Chemistry. Marcel Decker Inc., New York.

Uehara, G, and G Gillman. 1982. The Mineralogy, Chemistry and Physics of Tropical Soil with Variable Charge Clays. Westview Press, Boulder, Colorado.

Whiteley, GM, and AR Dexter. 1984. Displacement of soil aggregates by elongating roots and emerging shoots of crop plants. Plant and Soil. 77: 131-140.

Yulnafatmawita, A. 2006. Hubungan antara status Corganik tanah dan stabilitas agregat Ultisol Limau Manis akibat perubahan penggunaan lahan. Prosiding Seminar BKS Barat di Jambi 26-28 April.

Yulnafatmawita, A, Saidi, Gusnidar, Adrinal dan Suyoko. 2010. Peranan bahan hijauan tanaman dalam peningkatan bahan organik dan stabilitas agregat tanah Ultisol Limau Manis yang ditanami jagung (Zea mays). J. Solum. 7(1): 37-48.

Yulnafatmawita, A, RA Naldo, dan A Rasyidin. 2012. Analisis sifat fisika Ultisol tiga tahun setelah pemberian bahan organik segar di daerah tropis basah Sambar. J. Solum. 9 (2): 91-97.

Zorita, D, JH Grov, and E Perfect. 2005. Soil fragment size distribution and compactive effort effects on maize root seedling elongation in moist soil. Crop Sci. 45:14171426.

Zuraida, R. 2010. Usaha tani padi dan jagung manis pada lahan tadah hujan untuk mendukung ketahanan pangan di Kalimantan Selatan (Kasus di Kec. Landasan Ulin Kotamadya Banjarbaru). Prosiding Pekan Serealia Nasional. ISBN: 978-979-8940-29-3. 